\title{
Pengaruh Aktivitas Fisik terhadap Penurunan Berat Badan dan Tingkat Kolesterol pada Orang dengan Obesitas: Literature Review
}

\section{Effect of Physical Exercise on Weight Loss and Cholesterol Levels in Obese People: Literature Review}

\author{
Aziz Ar Rafiq ${ }^{1}$, Sutono ${ }^{2}$, Anggi Lukman Wicaksana ${ }^{3 *}$ \\ ${ }^{1}$ Program Studi Ilmu Keperawatan, Fakultas Kedokteran, Kesehatan Masyarakat, dan \\ Keperawatan, Universitas Gadjah Mada \\ ${ }^{2}$ Departemen Keperawatan Dasar dan Emergensi, Fakultas Kedokteran, Kesehatan \\ Masyarakat, dan Keperawatan, Universitas Gadjah Mada \\ ${ }^{3}$ Departemen Keperawatan Medikal Bedah, Fakultas Kedokteran, Kesehatan Masyarakat, \\ dan Keperawatan, Universitas Gadjah Mada
}

\begin{abstract}
Background: Obesity is a complex condition, has many risk factors, but it can be prevented. People with obesity have high cholesterol levels and often have difficulty in losing weight. Moreover, physical exercise has vital role for reducing weight for people with obesity, since physical exercise affects one third of body's energi expenditure.

Objective: To review the effect of physical exercise on weight loss and cholesterol levels in obese people.

Methods: Three electronic data sources, namely Scopus, PubMed, and Science Direct were explored for literature search. PICO was used along with few keywords i.e., obesity, physical activity or physical exercise or exercise, weight, and cholesterol. The search was resulted in seven literatures that matched the inclusion criteria, namely published on electronic data sources between 2008 to 2018, quantitative research, using population of people with obesity aged 20-60 years, English language literature and available in full text. The selected literatures were analyzed by descriptive narrative method and data extraction.

Results: These literatures consisted of two case study and five randomized-controlled trial method. According to literature review, physical activity influenced weight loss and cholesterol levels. Physical activity was ranging form moderate intensity exercise, walking, aerobic to endurance training programs. Conclusion: Physical exercise influences on weight loss and cholesterol level in people with obesity. Furthermore, it gives positive influence toward body condition, such as improving metabolism, quality of life, self efficacy, and cardiorespiratory fitness.
\end{abstract}

Keywords: cholesterol, obesity, physical activity

\begin{abstract}
ABSTRAK
Latar belakang: Obesitas merupakan suatu keadaan yang kompleks dan memiliki banyak faktor risiko, tetapi besar kemungkinannya untuk dicegah. Orang dengan obesitas memiliki tingkat kolesterol yang tinggi dan sering mengalami kesulitan dalam menurunkan berat badan. Aktivitas fisik memiliki peran penting bagi orang yang mengalami obesitas untuk menurunkan berat badan, karena satu pertiga pengeluaran energi tubuh dihasilkan melalui aktivitas fisik.

Tujuan: Mengulas pengaruh aktivitas fisik terhadap penurunan berat badan dan tingkat kolesterol pada orang dengan obesitas.

Metode: Pencarian literatur dilakukan di tiga sumber data elektronik, yaitu Scopus, PubMed, dan Science Direct. Pencarian tersebut menggunakan PICO dengan kata kunci obesity, physical activity atau physical exercise atau exercise, weight dan cholesterol. Dari pencarian tersebut ditemukan 7 literatur yang sesuai dengan kriteria inklusi, yaitu literatur terbit pada sumber data elektronik dari tahun 2008 hingga 2018, merupakan jenis penelitian kuantitatif, dengan populasi orang obesitas berusia 2060 tahun, literatur berbahasa Inggris dan tersedia dalam teks lengkap. Literatur terpilih selanjutnya dianalisis dengan metode naratif deskriptif dan dilakukan ekstraksi data.
\end{abstract}

Corresponding Author: Anggi Lukman Wicaksana

Gedung Ismangoen, Kompleks FKKMK UGM, Jl.Farmako Sekip Utara, Sendowo, Sinduadi, Mlati, Sleman, Yogyakarta 55281

Email: anggi.l.wicaksana@ugm.ac.id 
Hasil: Tujuh literatur terpilih terbagi menjadi dua literatur studi kasus dan lima literatur uji acak terkendali. Hasil dari tujuh literatur tersebut yaitu bahwa aktivitas fisik memiliki pengaruh terhadap penurunan berat badan dan tingkat kolesterol. Aktivitas fisik yang dilakukan bervariasi, mulai dari latihan intensitas sedang, jalan kaki, aerobik, hingga program latihan ketahanan.

Kesimpulan: Aktivitas fisik memiliki pengaruh terhadap penurunan berat badan dan tingkat kolesterol pada orang dengan obesitas. Aktivitas fisik dapat menimbulkan pengaruh yang baik terhadap tubuh, yaitu memperbaiki metabolisme tubuh, meningkatkan kualitas hidup, meningkatkan efikasi diri dan meningkatkan kebugaran kardiorespirasi.

Kata kunci: aktivitas fisik, kolesterol, obesitas

\section{PENDAHULUAN}

Obesitas merupakan suatu kondisi yang kompleks, dengan banyak faktor risiko, dan besar kemungkinannya untuk dicegah. Data WHO menunjukkan bahwa secara fisiologis, obesitas didefinisikan sebagai suatu kondisi kelebihan lemak yang terakumulasi secara tidak normal di jaringan adiposa sampai kadar tertentu sehingga mengganggu kesehatan. ${ }^{1}$

Obesitas dan berat badan berlebih diderita oleh sepertiga populasi penduduk di dunia saat ini. ${ }^{2}$ Menurut data $\mathrm{WHO}$, sekitar 650 juta penduduk dewasa di dunia mengalami obesitas, serta 340 juta anak-anak dan remaja berusia 5 sampai 19 tahun, mengalami berat badan berlebih. $^{3}$

Tingginya prevalensi kejadian obesitas yang meningkat setiap tahun di Indonesia menyebabkan dampak buruk terhadap kesehatan. Beberapa dampak yang ditimbulkan oleh obesitas antara lain gangguan sistem kardiovaskuler (artherosclerosis, dislipidemia), gangguan sistem pernapasan (Obstructive Sleep Apneu, Obesity Hypoventilation Syndrome), dan gangguan sistem endokrin (hipotiroid, diabetes). ${ }^{4}$

Orang dengan obesitas cenderung memiliki tingkat kolesterol yang tinggi dan sering mengalami kesulitan menurunkan berat badan. Oleh sebab itu, dalam program penurunan berat badan, diperlukan pembatasan asupan dan pengaturan pengeluaran kolesterol dalam tubuh. ${ }^{5}$ Kolesterol bermanfaat bagi tubuh sebagai penunjang pembuatan hormon testosteron, hormon kortisol, hormon estrogen, vitamin $\mathrm{D}$, dan asam empedu untuk mencerna lemak dari makanan. Akan tetapi, kadar kolesterol yang berlebihan dalam tubuh dapat menyebabkan penumpukan lemak pada dinding arteri sehingga aliran darah dapat tersumbat.

Aktivitas fisik memiliki peran penting bagi orang dengan obesitas untuk menurunkan berat badan karena satu pertiga pengeluaran energi tubuh dihasilkan melalui aktivias fisik. ${ }^{6}$ Aktivitas fisik yang berat secara langsung memerlukan tenaga yang besar, tenaga tersebut diperoleh dari cadangan lemak tubuh yang diubah menjadi energi. ${ }^{7}$ Selain itu aktivitas fisik diketahui juga dapat memengaruhi kadar kolesterol dan LDL. Aktivitas fisik yang teratur akan meningkatkan aktivitas enzim lipoprotein lipase (LPL) dan menurunkan aktivitas enzim hepatic lipase. Lipoprotein lipase membantu memindahkan LDL dari darah ke hati, kemudian diubah menjadi empedu atau disekresikan sehingga kadar LDL dan kadar kolesterol menurun. ${ }^{8}$ 
Berdasarkan pemaparan, aktivitas fisik memiliki peran dalam program penurunan berat badan dan tingkat kolesterol pada penderita obesitas, maka peneliti ingin mengetahui lebih mendalam mengenai pengaruh aktivitas fisik terhadap penurunan berat badan dan tingkat kolesterol pada penderita obesitas.

\section{METODE PENELITIAN}

Penelitian ini merupakan penelitian literature review. Penelitian ini memiliki dua jenis variabel yaitu variabel bebas dan variabel terikat. Variabel bebas dalam penelitian ini yaitu aktivitas fisik, dengan variabel terikat yaitu berat badan dan tingkat kolesterol.

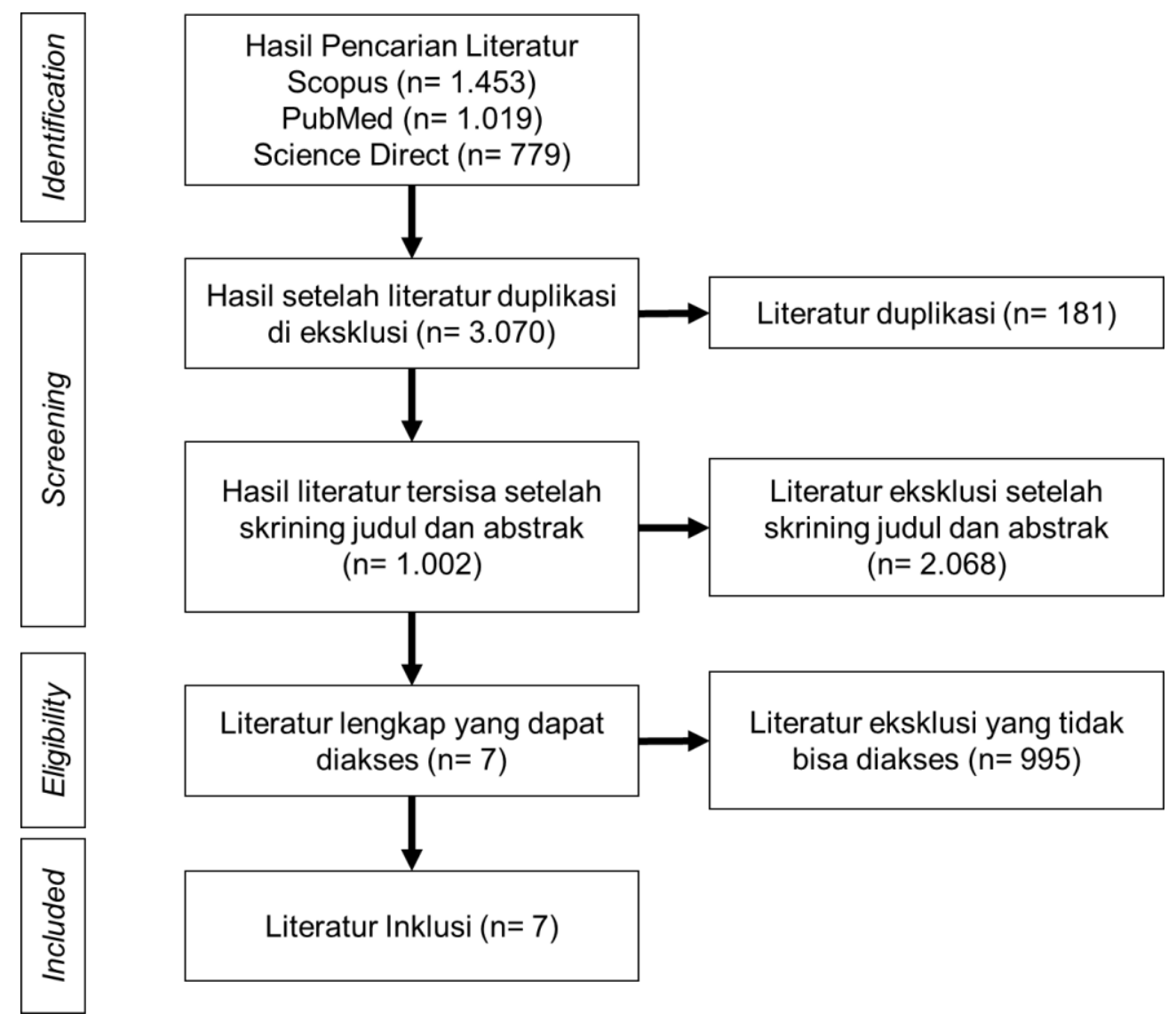

\section{Gambar 1. PRISMA Flow Diagram}

Proses pemilihan artikel terdiri dari beberapa tahap, yaitu: identification, screening, dan eligibility (Gambar 1). Tahap pertama adalah identifikasi yaitu dengan menentukan PICO dan pertanyaan penelitian. PICO dalam penelitian ini yaitu Population: obesity, Intervention: physical activity or physical exercise or exercise, Control: tidak ada, dan Outcome: weight and cholesterol. Sehingga pertanyaan dari penelitian ini yaitu 'Bagaimana pengaruh aktivitas fisik terhadap penurunan berat badan dan tingkat kolesterol pada orang dengan obesitas?'. Peneliti menggunakan 3 sumber data pencarian yaitu Scopus, Pubmed dan Science Direct.

Tahap kedua adalah screening yaitu penyaringan literatur. Semua literatur dikaji dan disaring berdasarkan judul, abstrak, dan isi dengan kriteria inklusi dan eksklusi. Kriteria inklusi 
dan ekslusi penelitian ini adalah literatur terbit pada sumber data elektronik dari tahun 2008 hingga 2018, merupakan jenis penelitian kuantitatif, populasi yaitu orang obesitas dengan IMT $\geq 25,00$, berbahasa Inggris dan tersedia dalam teks lengkap. Berdasarkan penyaringan, didapatkan sebanyak 2.068 literatur dieksklusi karena tidak sesuai dengan kriteria inklusi yang dimaksud.

Tahapan selanjutnya adalah eligibility yaitu tahap penyaringan kembali literatur yang dapat diakses secara bebas/tidak berbayar. Berdasarkan pencarian, literatur yang eligible adalah sebanyak tujuh literatur dengan kategori open access, sehingga dalam tahap akhir yaitu sebanyak tujuh literatur yang digunakan peneliti.

\section{HASIL}

Hasil ekstraksi 7 artikel yang didapat ditampilkan pada Tabel 1.

Tabel 1. Hasil ekstraksi artikel $(n=7)$

\begin{tabular}{|c|c|c|c|c|c|}
\hline $\begin{array}{l}\text { Penulis dan } \\
\text { Judul }\end{array}$ & $\begin{array}{l}\text { Tujuan } \\
\text { Penelitian }\end{array}$ & $\begin{array}{c}\text { Desain } \\
\text { Penelitian }\end{array}$ & Responden & Metode Penelitian & Hasil \\
\hline $\begin{array}{l}\text { Rosenkilde et. al. } \\
2018 \\
\text { "Exercise and } \\
\text { Weight Loss } \\
\text { Effects on } \\
\text { Cardiovascular } \\
\text { Risk Factors in } \\
\text { Overweight Men"9 }\end{array}$ & $\begin{array}{l}\text { Menyelidiki } \\
\text { pengaruh } \\
\text { independent dan } \\
\text { gabungan antara } \\
\text { latihan olahraga } \\
\text { dan program } \\
\text { penurunan berat } \\
\text { badan pada } \\
\text { lipoprotein bagi } \\
\text { pria dengan } \\
\text { berat badan } \\
\text { berlebih. }\end{array}$ & Study Design & $\begin{array}{l}\text { Random sampling: } \\
(\mathrm{n}=60) \\
\text { Latihan ketahanan } \\
(\mathrm{T})(\mathrm{n}=17) \\
\text { Rerata berat } \\
\text { badan: } 94,5 \mathrm{~kg} . \\
\text { Rerata LDL: } 112 \\
\text { mg/dl. } \\
\text { Diet pengurangan } \\
\text { energi (D) } \\
\text { ( } \mathrm{n}=15) \text {. } \\
\text { Rerata berat } \\
\text { badan: } 91,2 \mathrm{~kg} . \\
\text { Rerata LDL: } 108 \\
\text { mg/dl. } \\
\text { Latihan dan diet } \\
\text { peningkatan } \\
\text { energi (T-iD) } \\
\text { ( } \mathrm{n}=13) \\
\text { Rerata berat } \\
\text { badan: } 96,0 \mathrm{~kg} \\
\text { Rerata LDL: } 104 \\
\text { mg/dl } \\
\text { Kontrol (C) } \\
(\mathrm{n}=15) \\
\text { Rerata berat } \\
\text { badan: } 92,2 \mathrm{~kg} \\
\text { Rerata LDL: } 108 \\
\text { mg/dl }\end{array}$ & $\begin{array}{l}\text { Intervensi dilakukan } \\
\text { selama } 12 \text { minggu } \\
\text { untuk semua } \\
\text { kelompok. } \\
\text { Kelompok T dan } \\
\text { T-iD melakukan } \\
\text { latihan } 3 \text { kali per } \\
\text { minggu dengan } \\
\text { intensitas tinggi } \\
\text { menggunakan } \\
\text { treadmill, sepeda } \\
\text { statis, dan rowing } \\
\text { technic. } \\
\text { Kelompok D } \\
\text { melakukan diet } \\
\text { dengan mengurangi } \\
\text { asupan energi } \\
\text { sebesar } 600 \text { kkal } \\
\text { per hari. Sementara } \\
\text { kelompok T-iD } \\
\text { meningkatkan } \\
\text { asupan energi } \\
\text { sebesar } 600 \text { kkal } \\
\text { per hari. } \\
\text { Kelompok C tidak } \\
\text { mendapatkan } \\
\text { intervensi. } \\
\text { Semua kelompok, } \\
\text { kecuali kelompok } \mathrm{C} \text {, } \\
\text { bertemu dengan staf } \\
2 \text { kali per minggu } \\
\text { untuk memastikan } \\
\text { kepatuhan pada } \\
\text { latihan dan diet yang } \\
\text { diberikan }\end{array}$ & 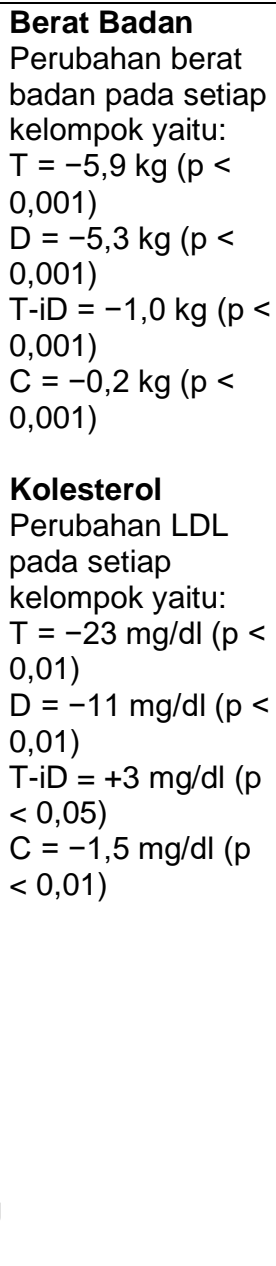 \\
\hline
\end{tabular}


Tabel 1. Hasil ekstraksi artikel ( $n=7)$ (lanjutan)

\begin{tabular}{|c|c|c|c|c|c|}
\hline $\begin{array}{l}\text { Penulis dan } \\
\text { Judul }\end{array}$ & $\begin{array}{c}\text { Tujuan } \\
\text { Penelitian }\end{array}$ & $\begin{array}{l}\text { Desain } \\
\text { Penelitian }\end{array}$ & Responden & Metode Penelitian & Hasil \\
\hline $\begin{array}{l}\text { Weiss et al. } 2016 \\
\text { "Effects of } \\
\text { Matched Weight } \\
\text { Loss from Calorie } \\
\text { Restriction, } \\
\text { Exercise, } \\
\text { or Both on } \\
\text { Cardiovascular } \\
\text { Disease Risk } \\
\text { Factors: A } \\
\text { Randomized } \\
\text { Intervention } \\
\text { Trial. "10 }\end{array}$ & $\begin{array}{l}\text { Mengetahui } \\
\text { pengaruh } \\
\text { pembatasan } \\
\text { kalori (CR) atau } \\
\text { latihan (EX) } \\
\text { dibandingkan } \\
\text { dengan CREX } \\
\text { terhadap faktor } \\
\text { risiko penyakit } \\
\text { kardiovaskular. }\end{array}$ & $\begin{array}{l}\text { Randomized } \\
\text { Intervention } \\
\text { Trial }\end{array}$ & $\begin{array}{l}\text { Pria dan wanita } \\
\text { yang memiliki } \\
\text { berat badan } \\
\text { berlebih dan } \\
\text { menetap } \\
(\mathrm{n}=52) . \\
\text { Berusia } 45-65 \\
\text { tahun) } \\
\text { CR: } \mathrm{n}=17 \\
\text { Rerata umur: } 57 \\
\text { tahun. } \\
\text { Rerata berat } \\
\text { badan: } 77,9 \mathrm{~kg} . \\
\text { Rerata total } \\
\text { kolesterol: } 202 \\
\text { mg/dl. } \\
\text { EX: } \mathrm{n}=16 \\
\text { Rerata umur: } 56 \\
\text { tahun. } \\
\text { Rerata berat } \\
\text { badan: } 78,1 \mathrm{~kg} . \\
\text { Rerata total } \\
\text { kolesterol: } 191 \\
\text { mg/dl. } \\
\text { CREX: } \mathrm{n}=19 \\
\text { Rerata umur: } 57 \\
\text { tahun. } \\
\text { Rerata berat } \\
\text { badan: } 82,4 \mathrm{~kg} . \\
\text { Rerata total } \\
\text { kolesterol: } 206 \\
\text { mg/dl. }\end{array}$ & $\begin{array}{l}\text { Intervensi dilakukan } \\
\text { selama } 12-14 \\
\text { minggu untuk } \\
\text { menurunkan berat } \\
\text { badan sebesar 6-8\% } \\
\text { dan defisit energi } \\
20 \% \text {. } \\
\text { Kelompok CR } \\
\text { mengurangi jumlah } \\
\text { asupan energi } \\
\text { dengan mengurangi } \\
\text { porsi makan dan } \\
\text { konsumsi makanan } \\
\text { tinggi serat. } \\
\text { Kelompok EX } \\
\text { meningkatkan } \\
\text { pengeluaran energi } \\
\text { melalui latihan 3-6 } \\
\text { kali /minggu dengan } \\
\text { intensitas sedang } \\
\text { atau tinggi. } \\
\text { Kelompok CREX } \\
\text { melakukan } \\
\text { intervensi gabungan } \\
\text { antara intervensi } \\
\text { kelompok CR dan } \\
\text { EX dengan } \\
\text { seimbang. }\end{array}$ & $\begin{array}{l}\text { Berat Badan } \\
\text { Perubahan berat } \\
\text { badan }(\mathrm{kg}) \text { pada } \\
\text { setiap kelompok } \\
\text { yaitu: } \\
\text { CR }=-5,4(\mathrm{p}< \\
0,0001) \\
\text { EX }=-5,6(\mathrm{p}< \\
0,0001) \\
\text { CREX }=-6,1(\mathrm{p}< \\
0,0001) \\
\text { Kolesterol } \\
\text { Perubahan total } \\
\text { kolesterol (mg/dl) } \\
\text { pada setiap } \\
\text { kelompok yaitu: } \\
\text { CR }=-15(p= \\
0,002) \\
\text { EX }=-14(p= \\
0,007) \\
\text { CREX = -22 ( } p< \\
0,0001)\end{array}$ \\
\hline $\begin{array}{l}\text { Gondim et al., } \\
2015 \\
\text { "Benefits of } \\
\text { Regular Exercise } \\
\text { on Inflammatory } \\
\text { and } \\
\text { Cardiovascular } \\
\text { Risk Markers in } \\
\text { Normal Weight, } \\
\text { Overweight and } \\
\text { Obese Adults"11 }\end{array}$ & $\begin{array}{l}\text { Mengetahui } \\
\text { pengaruh dari } 6 \\
\text { dan } 12 \text { bulan } \\
\text { pelatihan fisik } \\
\text { sedang pada } \\
\text { tingkat adipokin } \\
\text { dan risiko } \\
\text { penyakit } \\
\text { kardiovaskular } \\
\text { pada } \\
\text { sukarelawan } \\
\text { dengan berat } \\
\text { badan normal, } \\
\text { berat badan } \\
\text { berlebih, dan } \\
\text { obesitas. }\end{array}$ & $\begin{array}{l}\text { Randomized } \\
\text { Control Trial }\end{array}$ & $\begin{array}{l}143 \text { Responden } \\
\text { Normal Weight } \\
\text { Group (NWG) } \\
\text { ( } \mathrm{n}=32 \text { ) } \\
\text { Rerata umur: } 47 \\
\text { tahun } \\
\text { Rerata berat } \\
\text { badan: } 58 \mathrm{~kg} \\
\text { Overweight Group } \\
\text { (OVG) } \\
\text { ( } \mathrm{n}=59 \text { ) } \\
\text { Rerata umur: } 58 \\
\text { tahun } \\
\text { Rerata berat } \\
\text { badan: } 70 \mathrm{~kg} \\
\text { Obesity Group } \\
\text { (OBG) } \\
\text { ( } \mathrm{n}=52 \text { ) } \\
\text { Rerata umur: } 58 \\
\text { tahun } \\
\text { Rerata berat } \\
\text { badan: } 86 \mathrm{~kg}\end{array}$ & $\begin{array}{l}\text { Untuk semua } \\
\text { kelompok, intervensi } \\
\text { latihan fisik } \\
\text { dilakukan } 2 \text { kali per } \\
\text { minggu selama } 12 \\
\text { bulan. Setiap } \\
\text { intervensi berdurasi } \\
\text { selama } 60 \text { menit } \\
\text { dengan rincian: } 5 \\
\text { menit pemanasan; } \\
50 \text { menit latihan } \\
\text { aerobik dan latihan } \\
\text { ketahanan, } \\
5 \text { menit peregangan. } \\
\text { Evaluasi dilakukan } \\
\text { pada bulan } \\
\text { ke-6 dan ke-12 } \\
\text { untuk melihat } \\
\text { pengaruh dari } \\
\text { latihan fisik dan } \\
\text { menjaga kelompok } \\
\text { tetap homogen }\end{array}$ & $\begin{array}{l}\text { Dari ketiga } \\
\text { kelompok tidak } \\
\text { ada perubahan } \\
\text { signifikan dalam } \\
\text { parameter } \\
\text { antropometrik dan } \\
\text { komposisi tubuh. } \\
\text { Berat Badan } \\
\text { Perubahan berat } \\
\text { badan pada setiap } \\
\text { kelompok yaitu: } \\
\text { NWG }=+1(p=n s) \\
\text { OVG = } 0 \text { ( } p=n s) \\
\text { OBG = }-1 \text { ( } p=n s) \\
\text { Kolesterol } \\
\text { Perubahan HDL } \\
\text { (mg/dl) } \\
\text { pada setiap } \\
\text { kelompok yaitu: } \\
\text { NWG = } 0 \text { ( } p= \\
\text { ns) } \\
\text { OVG = } \Delta-6(p< \\
0,01) \\
\text { OBG = } \Delta-3(p< \\
0,05)\end{array}$ \\
\hline
\end{tabular}




\begin{tabular}{|c|c|c|c|c|c|}
\hline \multicolumn{6}{|c|}{ Tabel 1. Hasil ekstraksi artikel ( $n=7)$ (lanjutan) } \\
\hline $\begin{array}{l}\text { Penulis dan } \\
\text { Judul }\end{array}$ & $\begin{array}{c}\text { Tujuan } \\
\text { Penelitian }\end{array}$ & $\begin{array}{c}\text { Desain } \\
\text { Penelitian }\end{array}$ & Responden & Metode Penelitian & Hasil \\
\hline $\begin{array}{l}\text { Kim, } 2018 \\
\text { "Effects of } \\
\text { Exercise Using a } \\
\text { Mobile Device on } \\
\text { Cardiopulmonary } \\
\text { Function, } \\
\text { Metabolic Risk } \\
\text { Factors, and Self- } \\
\text { Efficacy in Obese } \\
\text { Women"12 }\end{array}$ & $\begin{array}{l}\text { Mengetahui } \\
\text { pengaruh dari } \\
\text { latihan berjalan } \\
12 \text { minggu } \\
\text { menggunakan } \\
\text { perangkat seluler } \\
\text { terhadap fungsi } \\
\text { kardiopulmoner, } \\
\text { faktor risiko } \\
\text { metabolik, dan } \\
\text { efikasi diri pada } \\
\text { wanita paruh } \\
\text { baya yang } \\
\text { gemuk. }\end{array}$ & Case Study & $\begin{array}{l}14 \text { subjek wanita } \\
\text { paruh baya } \\
\text { dengan obesitas. } \\
\text { Rerata umur: } \\
47,93 \text { tahun } \\
\text { Rerata tinggi } \\
\text { badan: } 158,61 \mathrm{~cm} \\
\text { Rerata berat } \\
\text { badan: } 68,69 \mathrm{~kg} \\
\text { Rerata lemak } \\
\text { tubuh: } 38,77 \% \\
\text { Rerata IMT: } 27,34 \\
\text { kg/m² } \\
\text { Rerata kolesterol } \\
\text { total: } \\
217,86 \mathrm{mg} / \mathrm{dl} \\
\text { Rerata HDL: } 54,79 \\
\text { mg/dl } \\
\text { Rerata trigliserida: } \\
131,64 \text { mg/dl }\end{array}$ & $\begin{array}{l}\text { Intervensi latihan } \\
\text { aerobik dilakukan } \\
\text { dengan latihan jalan } \\
\text { kaki } 3 \text { kali per } \\
\text { minggu selama } 12 \\
\text { minggu. Setiap } \\
\text { intervensi berdurasi } \\
\text { selama } 60-80 \text { menit. }\end{array}$ & $\begin{array}{l}\text { Berat Badan } \\
\text { Penurunan berat } \\
\text { badan }-1,46 \mathrm{~kg}(\mathrm{p} \\
=0,005), \text { dan } \\
\text { penurunan IMT } \\
-0,61 \mathrm{~kg} / \mathrm{m}^{2}(\mathrm{p}= \\
0,005) . \\
\text { Kolesterol } \\
\text { Terjadi penurunan } \\
\text { lemak tubuh } \\
-1,02 \% \text { ( } \mathrm{p}= \\
0,034), \text { penurunan } \\
\text { total kolesterol } \\
-1,50 \text { mg/dl ( } p= \\
0,849), \\
\text { peningkatan HDL } \\
+3,00 \text { mg/dl }(p= \\
0,037), \text { dan } \\
\text { penurunan } \\
\text { trigliserida }-6,86 \\
\text { mg/dl ( } p=0,618) .\end{array}$ \\
\hline $\begin{array}{l}\text { Wagmacker et al., } \\
2017 \\
\text { "Metabolic } \\
\text { Reponses to a } \\
\text { Physical Exercise } \\
\text { Session in Women } \\
\text { with Excess Body } \\
\text { Mass: } \\
\text { Randomized } \\
\text { Clinical Trial"13 }\end{array}$ & $\begin{array}{l}\text { Mengetahui } \\
\text { pengaruh dari } \\
\text { latihan fisik } \\
\text { terhadap nilai } \\
\text { glikemia dan lipid } \\
\text { pada wanita } \\
\text { dengan berat } \\
\text { badan berlebih. }\end{array}$ & $\begin{array}{l}\text { Randomized } \\
\text { Clinical Trial }\end{array}$ & $\begin{array}{l}66 \text { wanita. } \\
\text { Rerata umur: } 24 \\
\text { tahun } \\
\text { Rerata IMT: } 29 \\
\text { kg/m² } \\
\text { Kelompok } \\
\text { eksperimental: } \\
\text { ( } \mathrm{n}=33 \text { ) } \\
\text { Rerata trigliserida: } \\
102 \text { mg/dl } \\
\text { Rerata kolesterol } \\
\text { total: } 159 \text { mg/dl } \\
\text { Rerata HDL: } 49 \\
\text { mg/dl } \\
\text { Rerata LDL: } 89 \\
\text { mg/dl } \\
\text { Kelompok kontrol: } \\
\text { (n=33) } \\
\text { Rerata trigliserida: } \\
\text { 99 mg/dl Rerata } \\
\text { kolesterol total: } \\
163 \text { mg/dl } \\
\text { Rerata HDL: } 45 \\
\text { mg/dl } \\
\text { Rerata LDL: } 97 \\
\text { mg/dl }\end{array}$ & $\begin{array}{l}\text { Intervensi dilakukan } \\
\text { selama } 48 \text { jam: } 1 \\
\text { jam evaluasi dan } \\
\text { penyampaian } \\
\text { rencana diet; } 11 \text { jam } \\
\text { tanpa intervensi; } 12 \\
\text { jam berpuasa, } \\
\text { kemudian } \\
\text { melakukan } \\
\text { pengambilan darah } \\
\text { pertama. } \\
12 \text { jam tanpa } \\
\text { intervensi } \\
12 \text { jam berpuasa } \\
\text { dengan tambahan } \\
\text { latihan fisik bagi } \\
\text { kelompok } \\
\text { eksperimental, } \\
\text { kemudian } \\
\text { pengambilan darah } \\
\text { kedua. } \\
\text { Kelompok } \\
\text { eksperimental } \\
\text { melakukan latihan } \\
\text { fisik dilakukan } \\
\text { menggunakan } \\
\text { treadmill ergonomi. } \\
\text { Intervensi dalam } 3 \\
\text { interval waktu. } \\
\text { Pemanasan } 7 \text { menit. } \\
\text { Pengondisian } \\
\text { hingga mencapai } \\
\text { pengeluaran energi } \\
\text { sebesar } 250 \text { kkal. } \\
\text { Pendinginan selama } \\
5 \text { menit. } \\
\text { Kelompok kontrol } \\
\text { tidak melakukan } \\
\text { latihan fisik. } \\
\end{array}$ & $\begin{array}{l}\text { Kolesterol } \\
\text { Perubahan } \\
\text { kolesterol pada } \\
\text { setiap kelompok } \\
\text { yaitu: } \\
\text { Kelompok } \\
\text { eksperimental: } \\
\text { Trigliserida }=-9 \\
\text { mg/dl }(p=0,08) \\
\text { Total kolesterol }= \\
+2 \mathrm{mg} / \mathrm{dl}(\mathrm{p}=0,36) \\
\mathrm{HDL}=+2 \mathrm{mg} / \mathrm{dl} \\
\text { ( } \mathrm{p}=0,04) \\
\text { LDL }=+2 \mathrm{mg} / \mathrm{dl} \\
(\mathrm{p}=0,27) \\
\text { Kelompok kontrol: } \\
\text { Trigliserida }=-5 \\
\mathrm{mg} / \mathrm{dl}(\mathrm{p}=0,06) \\
\text { Total kolesterol }=- \\
1 \mathrm{mg} / \mathrm{dl}(\mathrm{p}=0,77) \\
\mathrm{HDL}=0 \mathrm{mg} / \mathrm{dl} \\
(\mathrm{p}=0,09) \\
\mathrm{LDL}=0 \mathrm{mg} / \mathrm{dl} \\
(\mathrm{p}=0,69)\end{array}$ \\
\hline
\end{tabular}


Tabel 1. Hasil ekstraksi artikel ( $n=7)$ (lanjutan)

\begin{tabular}{|c|c|c|c|c|c|}
\hline $\begin{array}{l}\text { Penulis dan } \\
\text { Judul }\end{array}$ & $\begin{array}{c}\text { Tujuan } \\
\text { Penelitian }\end{array}$ & $\begin{array}{c}\text { Desain } \\
\text { Penelitian }\end{array}$ & Responden & Metode Penelitian & Hasil \\
\hline $\begin{array}{l}\text { Lee et al. } 2018 \\
\text { "Mobile Health, } \\
\text { Physical Activity, } \\
\text { and Obesity: } \\
\text { Subanalysis of a } \\
\text { Randomized } \\
\text { Controlled Trial"14 }\end{array}$ & $\begin{array}{l}\text { Mengetahui } \\
\text { pengaruh } \\
\text { penggunaan } \\
\text { smartphone } \\
\text { terhadap } \\
\text { manajemen } \\
\text { obesitas }\end{array}$ & $\begin{array}{l}\text { Randomized } \\
\text { Controlled Trial }\end{array}$ & $\begin{array}{l}324 \text { responden. } \\
\text { / } 177 \text { orang } \\
\text { kelompok } \\
\text { intervensi: } \\
52 \text { orang } \\
\text { kelompok Inactive } \\
\text { (IA), } \\
31 \text { orang } \\
\text { kelompok } \\
\text { Minimally Active } \\
\text { (MA) } \\
94 \text { orang } \\
\text { kelompok Health } \\
\text { Enhancing } \\
\text { Physical Activity } \\
\text { (HEPA) } \\
147 \text { orang } \\
\text { kelompok kontrol: } \\
\text { IA = 53 orang } \\
\text { MA = } 27 \text { orang } \\
\text { HEPA = } 67 \text { orang } \\
\end{array}$ & $\begin{array}{l}\text { Intervensi dilakukan } \\
\text { selama } 24 \text { minggu. } \\
\text { Semua kelompok } \\
\text { berkonsultasi } 1 \text { kali/ } \\
2 \text { bulan. } \\
\text { Kelompok intervensi } \\
\text { mendapatkan } \\
\text { manajemen obesitas } \\
\text { melalui smartphone } \\
\text { menggunakan } \\
\text { Aplikasi SmartCare. } \\
\text { Kelompok kontrol } \\
\text { mendapatkan } \\
\text { manajemen obesitas } \\
\text { tanpa melalui } \\
\text { smartphone. } \\
\text { Kelompok IA } \\
\text { melakukan latihan } \\
\text { intensitas ringan. } \\
\text { Kelompok MA } \\
\text { melakukan latihan } \\
\text { intensitas sedang. } \\
\text { Kelompok HEPA } \\
\text { melakukan latihan } \\
\text { intensitas tinggi. }\end{array}$ & 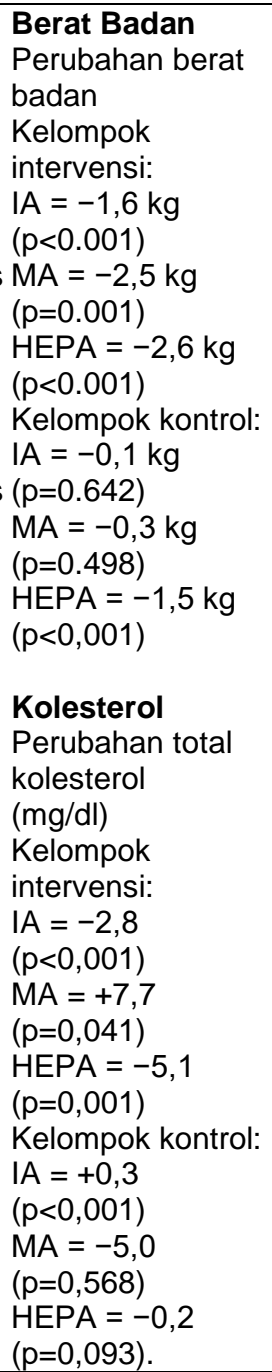 \\
\hline $\begin{array}{l}\text { Said MA, et al. } \\
\text { Multidisciplinary } \\
\text { Approach to } \\
\text { Obesity: Aerobic } \\
\text { or Resistance } \\
\text { Physical } \\
\text { Exercise?15 }\end{array}$ & $\begin{array}{l}\text { Membandingkan } \\
2 \text { program } \\
\text { multidisiplin yang } \\
\text { digunakan untuk } \\
\text { penurunan berat } \\
\text { badan. }\end{array}$ & $\begin{array}{l}\text { Randomized } \\
\text { Controlled } \\
\text { Intervention } \\
\text { Trial }\end{array}$ & $\begin{array}{l}\text { Rerata berat } \\
\text { badan: } 126,97 \mathrm{~kg} \\
\text { Rerata IMT: 39,98 } \\
\mathrm{kg} / \mathrm{m}^{2} \\
\text { Rerata lemak } \\
\text { tubuh: } 40,39 \% \\
\text { Dieting associated } \\
\text { with Resistance } \\
\text { Training (DRT): } \\
\text { ( } \mathrm{n}=23 \text { ) } \\
\text { Rerata berat } \\
\text { badan: } 96,28 \mathrm{~kg} \\
\text { Rerata IMT: } 31,98 \\
\mathrm{~kg} / \mathrm{m}^{2} \\
\text { Rerata lemak } \\
\text { tubuh: } 30,94 \% \\
\end{array}$ & $\begin{array}{l}\text { Intervensi dilakukan } \\
\text { selama } 16 \text { minggu. } \\
\text { Kelompok D } \\
\text { melakukan } \\
\text { penurunan berat } \\
\text { badan dengan } \\
\text { mengurangi asupan } \\
\text { kalori dan } \\
\text { menentukan } \\
\text { komposisi makanan } \\
\text { yang tepat, berupa } \\
\text { makanan } \\
\text { rendah lemak dan } \\
\text { rendah gula seperti } \\
\text { buah, sayuran, dan } \\
\text { sereal. } \\
\text { Kelompok DAT dan } \\
\text { DRT melakukan } \\
\text { penurunan berat } \\
\text { badan seperti } \\
\text { kelompok D } \\
\text { ditambah dengan }\end{array}$ & $\begin{array}{l}\text { Berat Badan } \\
\text { Perubahan berat } \\
\text { badan pada setiap } \\
\text { kelompok yaitu: } \\
\mathrm{D}=-6,03 \mathrm{~kg}(\mathrm{p}< \\
0.01) \\
\text { DAT }=-10,5 \mathrm{~kg} \mathrm{(p} \\
<0.001) \\
\text { DRT }=-9,37 \mathrm{~kg}(\mathrm{p} \\
<0,001) \\
\text { Perubahan IMT } \\
\text { pada setiap } \\
\text { kelompok yaitu: } \\
\mathrm{D}=-2,87 \mathrm{~kg} \\
(\mathrm{p}<0,001) \\
\text { DAT =-4,62 kg ( } p \\
<0,001) \\
\text { DRT = -3,9 kg ( } p \\
<0,001)\end{array}$ \\
\hline
\end{tabular}


Tabel 1. Hasil ekstraksi artikel ( $n=7)$ (lanjutan)

\begin{tabular}{|c|c|c|c|c|c|}
\hline $\begin{array}{l}\text { Penulis dan } \\
\text { Judul }\end{array}$ & $\begin{array}{c}\text { Tujuan } \\
\text { Penelitian }\end{array}$ & $\begin{array}{l}\text { Desain } \\
\text { Penelitian }\end{array}$ & Responden & Metode Penelitian & Hasil \\
\hline & & & & $\begin{array}{l}\text { latihan fisik. Latihan } \\
\text { fisik dilakukan } 3 \text { kali } \\
\text { per minggu dengan } \\
\text { tahapan 5-10 menit } \\
\text { pemanasan, diikuti } \\
\text { dengan latihan rutin } \\
\text { dan 5-10 menit } \\
\text { pendinginan. } \\
\text { Kelompok DAT } \\
\text { melakukan latihan } \\
\text { aerobik berupa } \\
\text { kombinasi lompatan. } \\
\text { Kelompok DRT } \\
\text { melakukan latihan } \\
\text { ketahanan dengan } \\
\text { meningkatkan } \\
\text { kekuatan otot } \\
\text { menggunakan alat. }\end{array}$ & $\begin{array}{l}\text { Kolesterol } \\
\text { Perubahan lemak } \\
\text { tubuh pada setiap } \\
\text { kelompok yaitu: } \\
\mathrm{D}=-4,62 \%(\mathrm{p}< \\
0,01) \\
\text { DAT }=-7,94 \%(\mathrm{p} \\
<0,001) \\
\text { DRT }=-6,34 \%(\mathrm{p} \\
<0,001) \\
\text { Perubahan total } \\
\text { kolesterol pada } \\
\text { setiap kelompok } \\
\text { yaitu: } \\
\text { (mg/dl) } \\
\text { D = } \Delta 1,00(\mathrm{p}< \\
0,01) \\
\text { DAT = } \Delta 5,84(\mathrm{p}< \\
0,001) \\
\text { DRT = } \Delta 2,78(\mathrm{p}< \\
0,01) \\
\text { Perubahan LDL } \\
\text { (mg/dl) pada } \\
\text { setiap kelompok } \\
\text { yaitu: } \\
\text { D }=\Delta 1,89(\mathrm{p}< \\
0,01) \\
\text { DAT = } \Delta 6,74(\mathrm{p}< \\
0,001) \\
\text { DRT = } \Delta 1,42(\mathrm{p}< \\
0,01) .\end{array}$ \\
\hline
\end{tabular}

Berdasarkan hasil pencarian literatur, terdapat tujuh literatur yang termasuk dalam kriteria. Enam dari tujuh artikel melihat pengaruh aktivitas fisik terhadap penurunan berat badan. Lima dari enam artikel menemukan latihan fisik berpengaruh terhadap penurunan berat badan. Terjadi penurunan berat badan secara signifikan $(-5,9 \mathrm{~kg} ; \mathrm{p}<0,001)$ setelah melakukan latihan ketahanan, ${ }^{9}(-5,6 \mathrm{~kg} ; \mathrm{p}<0,001)$ setelah melakukan exercise,${ }^{10}(-1,46 \mathrm{~kg} ; \mathrm{p}=0,005)$ setelah melakukan aerobik dan latihan jalan, ${ }^{12}(-2,6 \mathrm{~kg} ; \mathrm{p}<0,001)$ setelah melakukan latihan intensitas tinggi, ${ }^{14}$ dan adanya perubahan penurunan berat badan sebesar $(-10,5 \mathrm{~kg}$; $\mathrm{p}<0,001)$ dengan melakukan latihan aerobik berupa kombinasi lompatan. ${ }^{15}$ Namun, satu artikel dari Gondim ${ }^{11}$ menemukan bahwa latihan fisik tidak berpengaruh secara signifikan terhadap penurunan berat badan pada orang dengan obesitas.

Dari ketujuh artikel tersebut diperoleh hasil bahwa latihan fisik memengaruhi penurunan kolesterol. Terjadi penurunan kolesterol secara signifikan $(-23 \mathrm{mg} / \mathrm{dl} ; \mathrm{p}<0,01)$ setelah melakukan latihan ketahanan, ${ }^{9}(-22 \mathrm{mg} / \mathrm{dl} ; \mathrm{p}<0,0001)$ setelah melakukan exercise, ${ }^{10}(-6 ; \mathrm{p}$ $<0,01)$ setelah melakukan latihan fisik, ${ }^{11}(-6,86 \mathrm{mg} / \mathrm{dl} ; \mathrm{p}=0,618)$ setelah melakukan aerobik dan latihan jalan, ${ }^{12}$ (-9 mg/dl; $\left.p=0,001\right)$ setelah latihan fisik dan menjaga diet, ${ }^{13}(-5,1 \mathrm{mg} / \mathrm{dl} ; \mathrm{p}=$ $0,001)$ setelah melakukan latihan intensitas tinggi, $(-7,94 \% ; p=0,001)$ setelah melakukan latihan aerobik berupa kombinasi lompatan. ${ }^{15}$ 
Aktivitas fisik yang dapat menurunkan berat badan dan kolesterol dapat berupa latihan ketahanan seperti treadmill, sepeda statis, dan rowing technic yang diberikan selama 3 kali per minggu selama 12 minggu;9 latihan fisik 3-6 kali per minggu dengan intensitas sedang atau tinggi yang dipandu oleh instruktur; ${ }^{10}$ latihan aerobik yang dilakukan dengan latihan jalan kaki berdurasi selama 60-80 menit; ${ }^{12}$ latihan intensitas tinggi; ${ }^{14}$ serta latihan fisik yang dilakukan melalui tahapan 5-10 menit pemanasan, diikuti dengan latihan rutin aerobik berupa kombinasi lompatan, dan 5-10 menit pendinginan. ${ }^{15}$

Dari ketujuh artikel tersebut, aktivitas fisik diberikan bersamaan dengan kontrol diet untuk menurunkan berat badan dan kolesterol. Rosenkilde ${ }^{9}$ melihat perbedaan pemberian diet, latihan ketahanan, diet dan latihan ketahanan diperoleh hasil semua kelompok mengalami penurunan yang signifikan terhadap berat badan dan kolesterol. Weiss et al, ${ }^{10}$ meneliti perbedaan pemberian pembatasan kalori, latihan fisik, dan pembatasan kalori serta latihan fisik ditemukan hasil bahwa adanya perubahan berat badan dan perubahan total kolesterol pada setiap kelompok intervensi dengan rata-rata $p<0,0001$. Penurunan berat badan yang paling signifikan dari ketujuh artikel tersebut diperoleh dari artikel Said et $a \Gamma^{15}$, dengan pemberian dieting associated with aerobic dapat menurunkan $10,5 \mathrm{~kg}$ berat badan $(p<0,001)$.

\section{PEMBAHASAN}

Penelitian ini berupa literature review untuk mengulas pengaruh aktivitas fisik terhadap penurunan berat badan dan tingkat kolesterol pada orang dengan obesitas. Terdapat 7 artikel yang memenuhi kriteria. Sebanyak 6 literatur (Rosenkilde et al. ${ }^{9}$ Weiss et al. ${ }^{10}$ Gondim et al. ${ }^{11}$ Kim ${ }^{12}$ Wagmacker et al. ${ }^{13}$ dan Lee et al. ${ }^{14}$ ) memiliki kesamaan pada kriteria obesitas yaitu body mass index (BMI) sebesar $\geq 25 \mathrm{~kg} / \mathrm{m}^{2}$. Sementara pada literatur Said et al. ${ }^{15}$ terdapat standar kriteria lain yaitu sebesar $\geq 30 \mathrm{~kg} / \mathrm{m}^{2}$. Hal ini sesuai dengan kriteria inklusi penulis yaitu literatur yang dilakukan review memiliki body mass index (BMI) sebesar $\geq 25 \mathrm{~kg} / \mathrm{m}^{2}$. Dalam jurnal yang berjudul "Overweight and Obesity in Indonesia: Prevalence and Risk Factor - a Literature Review" menunjukkan bahwa $\mathrm{WHO}^{1}$ mengatakan yang dimaksud obesitas adalah individu dengan body mass index (BMI) sebesar $\geq 25 \mathrm{~kg} / \mathrm{m}^{2}{ }^{16}$

Hasil ketujuh literatur tersebut memiliki efek latihan fisik terhadap perubahan dan kondisi kesehatan tubuh. Dengan melakukan aktivitas fisik akan terjadi perubahan-perubahan pada tubuh menurut jenis, lama, dan intensitas latihan yang dilakukan. Secara umum, aktivitas fisik yang dilakukan secara teratur dengan takaran yang cukup, akan menyebabkan perubahan pada jantung, pembuluh darah, paru-paru, otot, ligamen, serta sendi.

Perubahan pada pembuluh darah berupa elastisitas pembuluh darah akan bertambah karena berkurangnya timbunan lemak dan penambahan kontraksi otot dinding pembuluh darah. Elastisitas pembuluh darah yang tinggi akan memperlancar jalannya darah dan mencegah timbulnya hipertensi. Selain elastisitas pembuluh darah yang meningkat, 
pembuluh-pembuluh darah kecil (kapiler) akan bertambah padat pula. Penyakit jantung koroner dapat diatasi dan dicegah dengan mekanisme perubahan ini. Kelancaran aliran darah juga akan mempercepat pembuangan zat-zat lelah sebagai sisa pembakaran sehingga diharapkan pemulihan kelelahan yang lebih cepat.

Perubahan pada jantung adalah jantung akan bertambah besar dan kuat sehingga daya tampung juga lebih besar dan denyutan kuat. Kedua hal ini akan meningkatkan efisiensi kerja jantung. Dengan efisiensi kerja yang tinggi, jantung tak perlu berdenyut terlalu sering. Pada orang yang tidak melakukan olahraga, denyut jantung rata-rata 80 kali per menit, sedang pada orang yang melakukan olahraga teratur, denyut jantung rata-rata 60 kali per menit. Dengan demikian, dalam satu menit dihemat 20 denyutan, dalam satu jam 1200 denyutan, dan dalam satu hari 28.800 denyutan. Penghematan tersebut menjadikan jantung awet dan kemungkinan hidup lebih lama dengan tingkat produktivitas yang tinggi.

Latihan fisik memiliki efek yang baik pada orang dengan obesitas. Penelitian menunjukkan bahwa program latihan dengan intensitas sedang dapat menurunkan kondisi inflamasi, meningkatkan fungsi sistem kardiovaskular, mengurangi kadar leptin, resistin dan tekanan darah diastolik dalam kelompok yang mengalami berat badan berlebih, serta leptin, resistin, IL-6 dan kadar homocysteine di dalam kelompok yang obesitas. ${ }^{11}$

Semua jenis aktivitas fisik baik untuk kesehatan, jika dilakukan secara teratur dan menjaga pola hidup sehat. Contohnya adalah berenang, lari, jalan cepat, senam, dan bersepeda, merupakan jenis aktivitas fisik yang mudah dan memiliki banyak manfaat. Dapat dikatakan bahwa dalam ketujuh literatur, memiliki banyak manfaat bagi kesehatan. ${ }^{17}$

Literatur Gondim et al. ${ }^{11}$ yang berjudul "Benefits of Regular Exercise on Inflammatory and Cardiovascular Risk Markers in Normal Weight, Overweight, and Obese Adults" menyebutkan bahwa tidak ada perubahan signifikan dalam parameter antropometrik dan komposisi tubuh di kelompok mana pun setelah 6-12 bulan latihan olahraga. Dalam literatur tersebut disebutkan bahwa terdapat perubahan berat badan pada setiap kelompok yaitu NWG $=+1(p=n s)$; OVG $=0(p=n s)$; dan OBG = $-1(p=n s)$. Hal ini dikarenakan intensitas latihan adalah 2 kali seminggu dengan waktu 1 kali sesi latihan adalah 60 menit. Hal tersebut bertentangan dengan program yang disarankan oleh Kementerian Kesehatan Republik Indonesia yang menyebutkan bahwa aktivitas fisik minimal dilakukan selama 150 menit/minggu. ${ }^{18}$ Selain itu, Gondim et al. ${ }^{11}$ juga tidak mengatur intake/output diet (nutrisi), sedangkan enam literatur lainnya, mengkaji dan melakukan intervensi terhadap diet respondennya.

Dari review literatur aktivitas fisik yang menghasilkan penurunan berat badan paling banyak adalah pada literatur Said et al. ${ }^{15}$ yaitu berjudul "Multidisciplinary Approach to Obesity: Aerobic or Resistance Physical Exercise?" Terdapat 3 kelompok intervensi dalam penelitian tersebut sehingga tingkat penurunan berat badan masing-masing adalah $6,03 \mathrm{~kg}$ pada kelompok D, 10,5kg pada DAT, dan 9,37kg pada DRT. Hasil dari literatur tersebut juga 
menjelaskan bahwa tidak hanya aktivitas fisik saja. Namun, pada kelompok yang hanya melakukan dieting group juga dapat menurunkan berat badan yaitu sebanyak $6,03 \mathrm{~kg}$. Kelompok yang menunjukkan hasil paling signifikan adalah DAT yaitu dengan intervensi berupa mengurangi asupan kalori dan menentukan komposisi makanan yang tepat, berupa makanan rendah lemak dan rendah gula seperti buah, sayuran dan sereal ditambah melakukan latihan aerobik berupa kombinasi lompatan 3x per minggu. Hal ini menunjukkan bahwa sebaiknya perlu penyeimbangan diet dan aktivitas fisik (kombinasi) dalam penurunan berat badan dan kolesterol supaya hasilnya lebih optimal.

\section{KESIMPULAN DAN SARAN}

Aktivitas fisik memiliki pengaruh terhadap penurunan berat badan dan tingkat kolesterol pada orang dengan obesitas. Jenis aktivitas fisik yang dapat menurunkan berat badan dan kolesterol yaitu latihan ketahanan, latihan 3-6 kali per minggu dengan intensitas sedang atau tinggi yang dipandu oleh instruktur, latihan aerobik dilakukan dengan latihan jalan kaki 3 kali per minggu selama 12 minggu, dengan setiap intervensi berdurasi 60-80 menit, latihan intensitas tinggi, dan latihan aerobik berupa kombinasi lompatan. Penurunan berat badan paling tinggi dijumpai pada intervensi yang mengombinasikan kontrol diet dan aktivitas fisik aerobik. Perawat dan tenaga kesehatan diharapkan dapat memberikan edukasi dan motivasi pada klien dengan obesitas untuk melakukan aktivitas fisik. Perlu dilakukan review lebih lanjut penggabungan antara intervensi diet dengan aktivitas fisik.

\section{UCAPAN TERIMA KASIH}

Terima kasih kepada semua pihak yang telah membantu dalam proses penelitian ini. Terima kasih kepada Program Studi IImu Keperawatan UGM.

\section{DAFTAR PUSTAKA}

1. Nishida C, Barba C, Cavalli-Sforza T, Cutter J, Deurenberg P, Darnton-Hill I, et al. Appropriate body-mass index for Asian populations and its implications for policy and intervention strategies. The Lancet [Internet]. 2004 Jan 10 [cited 2021 Nov 24];363(9403):157-63. Available from: http://www.thelancet.com/article/S0140673603152683/fulltext

2. American Medical Association. AMA Adopts New Policies on Second Day of Voting at Annual Meeting American Medical Association [Internet]. 2013 [cited 2020 Jun 5]. Available from: https://news.cision.com/american-medical-association/r/ama-adopts-new-policies-on-second-day-of-votingat-annual-meeting,c9430649.

3. World Health Organization. Obesity and overweight [Internet]. 2016 [cited 2020 May 6]. Available from: https://www.who.int/news-room/fact-sheets/detail/obesity-and-overweight.

4. Abraham M. Rudolph JIEHCDR. Buku Ajar Pediatri Rudolph 2. Buku Kedokteran EGC; 2007.

5. Hill JO, Wyatt HR, Peters JC. Energy Balance and Obesity. Circulation [Internet]. 2012 Jul 3 [cited 2021 Jul 6];126(1):126-32. Available from: http://circ.ahajournals.org.

6. J.B. Suharjo B. Cahyono. Gaya Hidup dan Penyakit Modern [Internet]. Yogyakarta: Kanisius; [cited 2021 Jul 6]. Available from: https://opac.perpusnas.go.id/DetailOpac.aspx?id=156541.

7. Dalilah. Hubungan Asupan Zat Gizi Makro dan Aktivitas Fisik dengan Status Gizi Pelajar SMA Muhammadiyah I Yogyakarta [Skripsi]. Yogyakarta: Fakultas Kedokteran, Kesehatan Masyarakat, dan Keperawatan, Universitas Gadjah Mada; 2009.

8. Thompson P.D., Rader D.J. 2001. Does Exercise Increase HDL Cholesterol in Those Who Need It The Most. Arteriosclerosis, Thrombosis, and Vascular Biology. American Heart Association, 21:1097-1098. 
9. Rosenkilde M, Rygaard L, Nordby P, Nielsen LB, Stallknecht B. Exercise and Weight Loss Effects on Cardiovascular Risk Factors in Overweight Men. J Appl Physiol [Internet]. 2018 [cited 2021 Jul 6];125(3):9018. Available from: https://pubmed.ncbi.nlm.nih.gov/29543138/

10. Weiss EP, Albert SG, Reeds DN, Kress KS, McDaniel JL, Klein S, et al. Effects of Matched Weight Loss from Calorie Restriction, Exercise, or Both on Cardiovascular Disease Risk Factors: A Randomized intervention trial. Am J Clin Nutr [Internet]. 2016 Sep 1 [cited 2021 Jul 6];104(3):576-86. Available from: https://pubmed.ncbi.nlm.nih.gov/27465384/

11. Gondim OS, De Camargo VTN, Gutierrez FA, De Oliveira Martins PF, Passos MEP, Momesso CM, et al. Benefits of Regular Exercise on Inflammatory and Cardiovascular Risk Markers in Normal Weight, Overweight and Obese Adults. PLoS One [Internet]. 2015 Oct 16 [cited 2021 Jul 6];10(10). Available from: https://pubmed.ncbi.nlm.nih.gov/26474157/

12. Kim DY. Effects of Exercise using A Mobile Device on Cardiopulmonary Function, Metabolic Risk Factors, and Self-Efficacy in Obese Women. J Exerc Rehabil [Internet]. 2018 Oct 1 [cited 2021 Jul 6];14(5):829-34. Available from: https://pubmed.ncbi.nlm.nih.gov/30443530/

13. Wagmacker DS, Petto J, Fraga AS, Matias JB, Mota SKA, Rodrigues LEA, et al. Metabolic Reponses to A Physical Exercise Session in Women with Excess Body Mass: Randomized Clinical Trial. Lipids Health Dis [Internet]. 2017 Dec 19 [cited 2021 Jul 6];16(1). Available from:/pmc/articles/PMC5735600/

14. Lee $\mathrm{CH}$, Cheung B, Yi GH, Oh B, Oh YH. Mobile Health, Physical Activity, and Obesity: Subanalysis of A Randomized Controlled Trial. Med (United States) [Internet]. 2018 Sep 1 [cited 2021 Jul 6];97(38). Available from: https://pubmed.ncbi.nlm.nih.gov/30235680/

15. Said MA, Abdelmoneem M, Almaqhawi A, Hamid Kotob AA, Alibrahim MC, Bougmiza I. Multidisciplinary Approach to Obesity: Aerobic or Resistance Physical Exercise? J Exerc Sci Fit. 2018 Dec 1;16(3):118-23.

16. Rachmi CN, Li M, Alison Baur L. Overweight and Obesity in Indonesia: Prevalence and Risk Factors-A Literature Review [Internet]. Vol. 147, Public Health. Elsevier B.V.; 2017 [cited 2021 Jul 6]. p. 20-9. Available from: https://pubmed.ncbi.nlm.nih.gov/28404492/

17. Pane BS. Peranan Olahraga dalam Meningkatkan Kesehatan. J Pengabdi Kpd Masy. 2015;21(79).

18. Kementerian Kesehatan Republik Indonesia. Aktivitas Fisik 150 Menit per Minggu agar Jantung Sehat Direktorat P2PTM [Internet]. 2018 Sept 28 [cited 2020 May 6]. Available from: http://www.p2ptm.kemkes.go.id/infographic-p2ptm/hipertensi-penyakit-jantung-dan-pembuluh-darah/aktivitasfisik-150-menit-per-minggu-agar-jantung-sehat 